\title{
Pelatihan Pembelajaran Daring Berbasis Aplikasi Google Di Masa Pandemik Covid-19 Di SMAN 8 Kota Bengkulu
}

\author{
Hery Haryanto ${ }^{1}$, Apriza Hongko Putra ${ }^{2}$, Heriansyah Heriansyah ${ }^{3}$ \\ ${ }^{123}$ Universitas Bengkulu \\ Email: heryharyanto@unib.ac.id
}

\section{Article History:}

Received: Desember 2020

Revised: Mei 2021

Accepted: Juni 2021

Available online: Juni

2021

\section{Kata Kunci:}

Covid19, Google, pandemi, PJJ, Sekolah

\begin{abstract}
Abstrak:
Pandemi Covid-19 telah menjadi darurat kesehatan global, banyak negara menerapkan social dan physical distancing. Hal tersebut berdampak langsung pada proses pembelajaran. Pandemi global ini telah berubah dari pembelajaran langsung menjadi pembelajaran online. Sebagian besar guru di sekolah belum menguasai pembelajaran online ini. Tujuan dari kegiatan sosialisasi ini adalah untuk melatih para guru menggunakan aplikasi berbasis Google untuk membuat, mengelola bahan ajar, dan menilai pembelajaran online. Pelatihan dilakukan dengan metode tatap muka dan pembelajaran mandiri. Sebagian besar peserta menyatakan bahwa materi pelatihan sangat puas dan bermanfaat untuk proses pembelajaran online. Kendala yang dihadapi peserta dalam melaksanakan pembelajaran online adalah: sinyal internet, pembelajaran karakter tidak terlihat. Kemampuan guru dalam memanfaatkan teknologi informasi di masa pandemi Covid-19 menjadi strategi yang sangat diperlukan, bahkan keahlian ini berguna dalam mempersiapkan era revolusi pendidikan 4.0
\end{abstract}




\section{Pendahuluan}

Pandemik Covid-19 yang awalnya merebak di kota Wuhan Tiongkok ditandai dengan infeksi saluran pernapasan akut. Pandemik ini menyebabkan kedarutan kesehatan global, dan Indonesia tidak luput dari penyebaran virus corona tersebut. Banyak negara terdampak Covid-19 melakukan social and physical distancing dan intervensi higinis untuk memutus penularan yang cepat dan masif. Wacana ini mungkin bisa berjalan lebih setahun. Pembatasan sosial berskala besar (PSBB) dan social and physical distancing berdampak secara langsung pada proses pembelajaran di lembaga pendidikan. Pandemik global ini telah merubah dari cara pembelajaran langsung tatap muka dengan pembelajaran daring. Sehingga pembelajaran daring merupakan suatu kebutuhan mutlak pada saat pembatasan sosial skala besar seperti saat ini.

Kondisi ini menimbulkan permasalahan bagaimana teknis pelaksanaan pembelajaran daring, sebab di lapangan banyak tenaga pendidik di sekolah belum siap dengan pembelajaran daring. Misalnya di SMAN 8 kota Bengkulu yang mempunyai sekitar 60 guru belum ada yang menerapkan synchronous learning selama masa pandemi Covid-19, atau materi pembelajaran yang terorganisir di sistem internet. Kegiatan PPM ini bertujuan untuk melatih para guru di sekolah ini untuk menggunakan pembelajaran daring berbasis aplikasi Google, yakni Google Drive, Google Classrom, dan Google Form. Penggunaan aplikasi pembelajaran berbasis Google ini berdasarkan kenyataan penyedia layanan teknologi informasi saat ini didominasi oleh Google, dan berbagai aplikasi berbasis Google berskala luas, mudah diakses oleh publik dengan menggunakan laptop, dan gawai berbasis adroid.

Wacana "bekerja dari rumah, belajar di rumah, dan ibadah di rumah" selalu tayang di media televisi, radio, dan media streaming pada setiap saat. Reporter TV selalu berpesan kepada pemirsa untuk selalu ingat pesan ibu "cuci tangan, makai masker, dan jaga jarak". Wacana tersebut terkait dengan merebaknya pandemik Covid-19 secara global. Dampak global pandemik Covid-19 telah mempegaruhi proses pembelajaran di segala tingkat pendidikan. Sehingga kebijaksanaan pelaksanaan working from home dan social and physical distancing perlu diterapkan untuk memutus penyebaran 
penularan Covid-19 (Cohen and Kupferschmidt, 2020; Ebrahim et al., 2020; Wilder-Smith and Freedman, 2020).

Penerapan working from home dan social and physical distancing legalitasnya dipayungi dengan Surat Edaran Menteri Pendidikan dan Kebudayaan nomor 4 tahun 2020 tentang Pelaksanaan Kebijakan Pendidikan Dalam Masa Darurat Penyebaran Corona Virus Diseases yang menekankan pada pembelajaran dari rumah (SE Mendekbud no 4/2020, tanggal 24 Maret 2020).

Penerapan PSBB bertujuan mengurangi frekuensi, lamanya kontak sosial dan fisik antar semua golongan umur. Tindakan menjaga jarak kontak dan tinggal di rumah dapat memutus penularan Covid-19. Penutupan sekolah dan perguruan tinggi, fasilitas penitipan anak, tempat hiburan, tempat peribadatan jamaah, dan tempat dimana orang banyak berkumpul adalah tindakan yang dapat dimaklumi (Ebrahim et al., 2020). Bahkan menurut pakar epidemiologis dari London School of Hygiene and Tropical Medicine, Adam Kucharski wacana social and physical distancing mungkin bisa berjalan lebih setahun (Anonim, 2020).

Penerapan PSBB menyebabkan pembelajaran langsung tatap muka ditiadakan sampai selesai masa darurat Covid-19, sebagai penggantinya adalah lembaga pendidikan diwajibkan untuk menggunakan pembelajaran daring, atau lebih dikenal dengan Pembelajaran Jarak Jauh (PJJ). Pembelajaran daring merupakan pembelajaran tanpa tatap muka secara langsung antara dosen/guru/instruktur dan mahasiwa/siswa/peserta kursuspelatihan. Kegiatan PJJ dengan menggunakan peralatan komunikasi elektronik (Komputer desktop/laptop, tablet, telpon genggam adroit/smartphone), sinyal telekomunikasi (internet, intranet) (Chaeruman, 2017).

PJJ memiliki karakteristik sebagai berikut : a. materi pembelajaran sesuai dengan tujuan pembelajaran, b. menggunakan berbagai metode pembelajaran untuk membantu terjadinya belajar seperti contoh dan latihan, c. menggunakan unsur-unsur media yang tepat seperti visual dan narasi untuk menunjang materi dan metode. Pembelajaran daring dapat dilakukan dengan 
strategi pembelajaran mandiri (asynchronus e-learning) yang didesain untuk tiap individu yang tergantung pada tersedianya waktu dan kecepatan pemahaman masing-masing peserta didik atau belajar secara klasikal dalam bentuk virtual classroom (synchronus e-learning) yang berlangsung secara bersamaan waktu untuk semua peserta didik dengan guru/dosennya (Chaeruman, 2017).

Perangkat lunak yang banyak digunakan dalam PJJ adalah aplikasi berbasis Google, antara lain Google Drive, Google Classroom, Google Form. Ketiga aplikasi ini digunakan secara saling terkait dan saling mendukung dalam proses pembelajaran daring. Google Drive merupakan fasilitas yang disediakan untuk pengelolaan penyimpanan materi bahan ajar. Google Classroom merupakan aplikasi interaktif antara dosen/guru dengan siswanya, sementara Google Form dapat digunakan sebagai evaluasi pembelajaran, yakni membuat latihan, tugas, dan soal soal ujian.

Google Classroom dapat digunakan untuk pembelajaran daring mulai sekolah dasar (Wicaksono and Rachmadyanti, 2018), sampai perguruan tinggi (Muslimah, 2018), dari subyek humaniora (Fitriningtiyas et al., 2019) sampai sains (Nurfalah, 2019). Google Classroom dapat mengakomodasikan aktivitas pembelajaran membaca teks, melihat gambar, mendengar audio, mendengar dan melihat video/animasi, mencoba dan mempraktekan dalam bentuk simulasi (Chaeruman, 2017). Misalnya pembelajaran bahasa Arab, selain mengajarkan tata bahasanya, juga mengajarkan fonetik (tajwid) secara virtual (Rozak and Albantani, 2018). Google Classroom juga menawarkan apakah bentuk pembelajaran mandiri, atau pembelajaran secara bersamaan waktunya (Chaeruman, 2017).

Survey terhadap peserta didik yang menggunakan Google Classrom menunjukkan peningkatan ketuntasan belajar, meningkatkan kreatifitas, komunikasi interaktif dua arah, dan kepuasan siswa terhadap proses pembelajaran (Shaharanee et al., 2019). Google Classroom dapat dijadikan media PJJ yang efisien, efektif serta interaktif untuk menunjang pembelajaran berbasis teknologi (Nurfalah, 2019). Penggunaan aplikasi berbasis Google dapat melatih dan mempersiapkan generasi mileneal menunju era revolusi industri 4.0. 
PSBB di tengah merebaknya wabah pandemik global Covid-19 sangat tepat waktunya untuk pelaksanaan PJJ, sehingga proses pembelajaran tetap berlangsung. Namun apabila masa wabah pendemik global Covid-19 berakhir, pembelajaran daring juga sangat diperlukan di era teknologi informasi. Sebab dengan pembelajaran daring, waktu dan tempat belajar sangat fleksibel.

Guru sebagai pendidik tugas utama adalah melakukan pembelajaran klasikal secara langsung di ruang kelas, namun di era kemajuan teknologi informasi guru harus mampu merancang, membuat, dan mengevaluasi materi mata pelajaran secara daring. Pembelajaran langsung tatap muka dibatasi waktu dan tempat, sebaliknya PJJ lebih fleksibel, tidak terbatas waktu dan tempat, dan dapat disesuaikan apakah akan berlangsung sebagai pembelajaran mandiri, atau akan berlangsung secara langsung (Qomariah et al., 2019)

Dalam konteks PSBB saat ini, dan pada keadaan normal sekalipun, penggunaan pembelajaran daring sangat membantu para tenaga pendidik dalam proses pembelajaran. Oleh karena itu di tengah merebaknya Covid-19 saat pelatihan penggunaan aplikasi berbasis Google bagi guru SMAN 8 Kota Bengkulu untuk merancang, mengkreasikan, mengevaluasi materi pembelajaran secara daring merupakan kegiatan yang dilakukan untuk menjaga keberlangsungan proses pembelajaran di sekolah.

\section{Metode}

Pelatihan PJJ dilaksanakan pada bulan Juli - Oktober 2020 diikuti oleh peserta 30 guru dari sekitar 60 guru yang ada di SMAN 8 Kota Bengkulu. Kegiatan pelatihan berlangsung 3 tahap, tahap pertama pembekalan materi, tahap kedua kegiatan mandiri dan diskusi dengan aplikasi WhatApp, tahap ketiga, presentasi dan evaluasi peserta. Sebelum berlangsung kegiatan pelatihan terlebih dahulu dilakukan komunikasi dengan Kepala Sekolah SMAN 8 terkait pelatihan pembelajaran, dan menyebarkan formulir pendaftaran. Persyaratan calon peserta pelatihan adalah sebagai berikut : mempunyai kemampuan dasar komputer, memahami pengetahuan internet, mempunyai laptop dan HP adroit/smarphone, dan dalam kondisi sehat. Calon peserta diminta untuk mengisi formulir pendaftaran. Peserta terpilih 
berdasarkan kriterea dan hasil konsultasi dengan Kepala Sekolah.

Kegiatan tahap pertama dilakukan secara langsung di ruang UNBK yang dilengkapi dengan perangkat komputer desktop. Dalam pelaksanaan ini instruktur dan peserta menggunakan masker, juga jika perlu menggunakan pelindung wajah. Kegiatan tahap pertama diisi dengan pembekalan materi terkait dengan pengelolaan materi ajar di Google Drive, penggunaan Google Classroom baik synchronous dan asynchronous learning, dan penggunaan Google Form untuk evaluasi pembelajaran.

Kegiatan mandiri berupa perancangan dan pembuatan materi pembelajaran tergantung bidang studi guru. Apabila ada kendala dan permasalahan didiskusikan lewat komunikasi aplikasi WhatApp. Pada tahap akhir para peserta mempresentasikan kreasi mereka di depan peserta yang lain, untuk mendapatkan saran untuk menghasilkan karya yang lebih baik. Pada tahap ini dilakukan evaluasi terhadap pelaksanan pelatihan dengan Google Form. Peserta yang mengikuti pelatihan dari awal sampai akhir dan dapat menunjukkan kreasinya mendapatkan sertifikat, dan menerima bantuan kuota internet senilai 100 ribu rupiah sebagai bantuan mengakses internet.

\section{Hasil}

Kemampuan peserta sangat bervariasi, ada yang sudah terbiasa menggunakan aplikasi platform google, tetapi kebanyakan peserta masih awam, bahkan beberapa guru baru mengenal apa itu Google Drive, Google Classroom, dan Google Form. Oleh karena itu, workshop pembelajaran daring di masa pandemik Covid-19 sangat tepat waktu dan tepat sasaran. Karena pada kenyataan di lapangan, banyak para guru masih belum menguasai metode PJJ dengan mengubah pembelajaran tatap muka langsung dengan pembelajaran daring. Dengan kondisi pandemik Covid-19 para guru dipaksa untuk berkreasi dalam mengelola materi pembelajaran, mengkreasikan materi secara daring, menyajikan baik secara synchronous dan asynchronous, dan membuat instrumen asesmen untuk mengevaluasi ketuntasan peserta didik. 


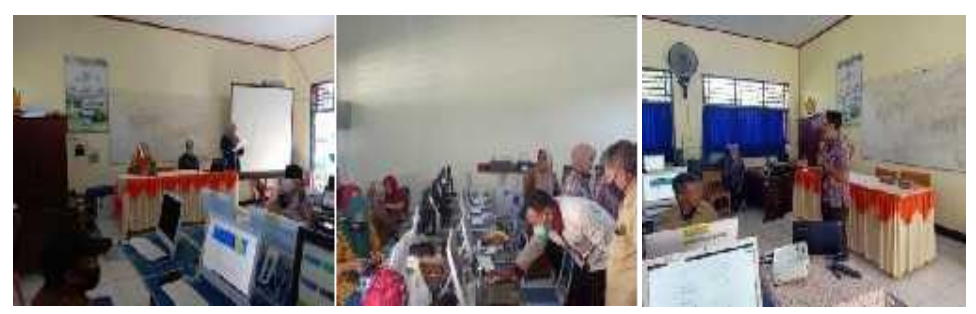

Gambar 1. Dokumentasi pelaksanaan kegiatan pelatihan PJJ

Pada topik pengelolaan materi dengan Google Drive, para peserta dapat memahami dan mempraktekkan cara mengelola materi ajar secara sistematis. Pada topik Google Classroom banyak peserta masih belum memahami bagaimana cara pembelajaran synchronous dan asynchronous, bagaimana menggunakan papan tulis virtual, bagaimana menggunakan presentasi power point, video, audio, mengisi daftar hadir. Dan pada topik Google Form para guru belajar bagaimana membuat tipe soal ujian (soal pilihan ganda, jawaban pendek, jawaban esai, perangkingan, dan lain-lain), rubrik penilaian, durasi waktu ujian, materi dan soal dengan notasi khusus, evaluasi fonetik pada pelajaran bahasa asing.

Kegiatan tahap pertama berlangsung dari jam 09.00 sampai 17.00. Dokumentasi kegiatan tersebut dapat dilihat pada Gambar 1. Banyak pertanyaan dan masalah yang dihadapi para guru dalam kreasi dan evaluasi pembelajaran. Pertanyaan dan masalah tersebut didiskusikan melalui komunikasi WhatApp group Kegiatan mandiri peserta pelatihan dilakukan sesuai waktu masing- masing guru, bila ada guru menghadapi kendala dalam kreasi pembuatan materi, pembuatan evaluasi pembelajaran dapat dikemukakan di grup WA untuk mendapat solusi.

Sampai tahap akhir ada 25 peserta dari 30 yang dapat menunjukkan hasil kreasi mereka. Evaluasi tersebut menunjukan sebagian besar peserta pelatihan ini sangat bermanfaat dan pemakaian pembelajaran daring dengan aplikasi berbasis google sangat membantu dalam pengelolaan materi bahan ajar, proses pembelajaran, dan evaluasi dan asesmen pembelaran siswa. 
Tabel 1. Kendala dalam pembelajaran daring

\begin{tabular}{clc}
\hline No & \multicolumn{1}{c}{ Per } & Prosentase \\
\hline 1 & Pembelajaran karakter tidak nampak & 60 \\
\hline 2 & Kuota internet dan tersedia gawai yang sesuai & 48 \\
\hline 3 & Sinyal internet yang tidak selalu bagus & 44 \\
\hline 4 & Tidak bisa tatap muka & 40 \\
\hline 5 & Kendala waktu & 9 \\
\hline
\end{tabular}

Kendala PJJ yang dihadapi para guru seperti yang tercantum pada Tabel 1. Contohnya : pada pembelajaran jarak jauh dengan internet, para guru mengalami kesulitan untuk menilai tingkah laku peserta didik selama proses pembelajaran. Sebab pembelajaran tidak hanya curah ilmu saja, tetapi juga ada pendidikan etika, sopan santun, budi pekerti. Karena para guru sulit mengamati perilaku melalui layar telpon genggam, lebih mudah mengamati pada pembelajaran secara langsung. Tetapi PJJ dengan internet ada segi positipnya, misalnya peserta didik yang biasanya pasif bertanya di pembelajaran secara langsung, di kelas virtual berani bertanya dan mengemukan pendapat. Kendala tidak adanya kuota, dan tersedia gawai yang sesuai, nampaknya tidak begitu menjadi masalah lagi. Apalagi sejak bulan Oktober 2020 Kemendikbud memberikan subsidi kuota internet pagi guru dan peserta didik sebagian kendala dapat teratasi.

\section{Diskusi}

Keadaan pandemik Covid-19 yang merubah proses pembelajaran dari tatap muka langsung menjadi pembelajaran secara langsung synchronous/virtual clasroom, atau pembelajaran asynchronous untuk tetap melangsung proses pembelajaran. Proses pembelajaran tidak boleh berhenti, walaupun menghadapi rintangan apapun. Karena pendidikan merupakan proses mencerdaskan peserta didik sebagai generasi penerus. Kemampuan para guru menguasai teknologi informasi pada saat pandemik Covid-19, atau saat tidak ada wabahpun, kemampuan pembelajaran daring seperti ini sangat 
penting di era kemajuan teknologi informasi yang berkembang sangar pesat.

Pendidikan memiliki peran vital dalam mempersiapkan individu global dan mencetak tenaga kerja berkualitas untuk masa mendatang. Hal ini tertuang dalam maklumat World Economic Forum (WEF), bahwa dunia saat ini membutuhkan metode Pendidikan 4.0 guna mendukung Revolusi Pendidikan 4.0. Pembelajaran di sekolah harus menuju ke Revolusi Pendidikan 4.0. yang dicirikan dengan kemampuan masyarakat global, kemampuan berinovasi dan berkreativitas, kemampuan teknologi, kemampuan interpersonal, dan pembelajaran yang telah dipersonalisasi sesuai karakteristik individu masing-masing (Kurniawan, 2020).)

\section{Kesimpulan}

Para guru SMAN 8 Kota Bengkulu meningkat kemampuannya dalam pengelolaan materi bahan ajar, menyelenggarakan proses pembelajaran secara daring, dan dapat melakukan evaluasi pembelajaran pada peserta didik dengan menggunakan aplikasi berbasis google. Kemampuan ini tidak hanya dipergunakan di masa pandemik Covid-19 seperti saat ini, tetapi pembelajaran daring dapat dilanjutkan pada masa normal dalam persiapan menuju era Revolusi Pendidikan 4.0.

\section{Ucapan Terima Kasih}

Tim PPM Ipteks mengucapkan terima kasih kepada LPPM Universitas Bengkulu atas dukungan finansial sesuai dengan Kontrak 2371/UN30.15/AM/2020, juga kepada Kepala Sekolah, para guru, dan staf tenaga kependidikan SMA Negeri 8 kota Bengkulu atas partisipasi dan bantuan sarananya, dan mahasiswa Universitas Bengkulu yang membantu pelaksanaan kegiatan ini.

\section{Daftar Referensi}

Anonim, (2020). Physical Distancing Akibat Virus Corona Bisa Berlangsung Setahun Lebih www.m.kumparan.com (accessed 4.5.20).

Chaeruman, U.A.( 2017). Alur Belajar?: Meningkatkan Interaktivitas Pembelajaran Daring. Presented at the Semiloka Pembelajaran Daring di Perguruan Tinggi, Kementerian Riset, Teknologi dan Pendidikan Tinggi. 
Cohen, J., Kupferschmidt, K. (2020). Countries Test Tactics in 'War' AgainstCovid-19. Science 367, 1287-1288.

Ebrahim, S.H., Ahmed, Q.A., Gozzer, E., Schlagenhauf, P., Memish, Z.A. (2020). Editorial?: Covid-19 and Community Mitigation Strategies in a Pandemic. BMJ (368) 1-2.

Fitriningtiyas, D.A., Umamah, N., Sumardi. (2019). Google Classroom: as a Media of Learning History. Earth and Environmental Science. Pp 1-8. Herdiyeni, Y., Poetri, O.N., Indrawan, D., Mustapha, Basri, C., Jaya, I., Mulyati, H. (2020). Model Prediksi Covid-19 di Indonesia untuk Perencanaan Mitigasi Resiko Terhadap Dampak Epidemiologi, Sosial dan Ekonomi. IPB University.

Kampf, G., Todt, D., Pfaender, S., Steinmann, E. (2020). Persistence of Coronaviruses on Inanimate Surfaces and Their Inactivation With Biocidal Agents. Journal of Hospital Infection 104, 246-251.

Kurniawan, A. (2020). Hadapi Revolusi Industri 4.0, Dunia Pendidikan HarusBagaimana?".www.kompas.com/edu/read/2020/04/03/ 162000071/. Accesed November 20, 2020

Muslimah, A. (2018). A Survey on The Use of Google Classroom in English Language Education. Thesis : Department of Islamic University of Indonesia.

Nurfalah, E. (2019). Optimalisasi E-Learning berbasis Virtual Class dengan Google Classroom sebagai Media Pembelajaran Fisika. Physics Education Research Journal, 46-55.

Qomariah, S., Lailiyah, S., Nursobah. (2019). Implementasi Pemanfaatan Google Classroom untuk Pembelajaran di Era Revolusi 4.0. Presented at the Sindimas, STMIK, Pontianak, pp. 227-231.

Rozak, A., Albantani, A.M. (2018). Desain Perkuliahan Bahasa Arab Melalui Google Classroom. Arabiyat 5, 83-102.

Shaharanee, I.N.M., Jamil, J.M., Rodzi, S.S.M. (2019). The Application of Google Classroom as a Tool for Teaching and Learning. Journal of Telecommunication, Electronic and Computer Engineering (8),1 - 4.

Wicaksono, V.D., Rachmadyanti, P. (2018). Pembelajaran Blended Learning Melalui Google Classroom di Sekolah Dasar. Presented at : Seminar Nasional Pendidikan PGSD UMS \& HDPGSDI Wilayah Jawa. pp.513-520.

Wilder-Smith, A., Freedman, D.O. (2020). Isolation, Quarantine, Social Distancing and Community Containment: Pivotal Role for Old-Style Public Health Measures in The Novel Coronavirus (2019 n-Cov) Outbreak. Journal of Travel Medicine 27, 1-4. 